\title{
Two new polychaete species living in the mantle cavity of Calyptogena gallardoi (Bivalvia: Vesicomyidae) at a methane seep site off central Chile $\left(\sim 36^{\circ} \mathrm{S}\right)$
}

\author{
EDUARDO QUIROGA ${ }^{1}$ and JAVIER SELLANES ${ }^{2,3}$ \\ ${ }^{1}$ Centro de Investigación en Ecosistemas de la Patagonia (CIEP), Bilbao 449, Coyhaique, Chile. \\ E-mail: eduardo.quiroga@ciep.cl \\ ${ }^{2}$ Universidad Católica del Norte, Departamento de Biologia Marina, Facultad de Ciencias del Mar, Larrondo 1281, \\ Coquimbo, Chile. \\ ${ }^{3}$ Centro de Investigación Oceanográfica en el Pacífico Sur-Oriental (COPAS), Universidad de Concepción, Casilla 160-C, \\ Concepción, Chile.
}

\begin{abstract}
SUMMARY: Two new polychaete species belonging to Nautiliniellidae and Antonbruunidae were found in the mantle cavity of the vesicomyid bivalve Calyptogena gallardoi Sellanes and Krylova, 2005, at a methane seep site off central Chile. Shinkai robusta $\mathrm{n}$. sp. is characterized by having modified parapodia with robust notopodia and nine simple hooks per parapodium on the middle setigers, and an anteriorly truncated sub-triangular prostomium, with a pair of small cirriform antennae. The new species closely resembles Shinkai longipedata Miura and Ohta, 1991, and Shinkai semilonga Miura and Hashimoto, 1996. Antonbruunia gerdesi $\mathrm{n}$. sp. is characterized by having a trapezoidal prostomium, with five sub-equal occipital antennae and a conspicuous pygidium with two short, well-developed digitiform anal cirri. These two new species constitute the first report of polychaetes living in symbiosis with chemosymbiotic bivalves in the south-eastern Pacific.
\end{abstract}

Keywords: methane seep, Nautiliniellidae, Antonbruunidae, symbiont polychaetes, Chile.

RESUMEN: Dos nuevas especies de poliquetos que habitan la CaVidad del manto de CaLyptogena GallaRdol (Bivalvia: Vesicomyidae) En Un afloramiento de Metano frente a Chile Central $\left(36^{\circ} \mathrm{S}\right)$. - Dos nuevas especies de poliquetos simbiontes pertenecientes a las familias Nautiliniellidae y Antonbruunidae se encontraron en la cavidad del manto del bivalvo vesicómyido Calyptogena gallardoi Sellanes y Krylova, 2005, proveniente de una zona de afloramiento de metano frente a Chile central. Shinkai robusta $\mathrm{n}$. sp. se caracteriza por presentar parapodios modificados con notopodios bien desarrollados y robustos, nueve setas simples por parapodio en la región media del cuerpo y un prostomio sub-triangular, truncado anteriormente, con un par de pequeñas antenas cirriformes. La nueva especie es similar a Shinkai longipedata Miura y Ohta, 1991, y Shinkai semilonga Miura y Hashimoto, 1996. Antonbruuniia gerdesi n. sp. se caracteriza por presentar un prostomio trapezoidal, con cinco antenas occipitales sub-iguales, incluyendo una antena central bien desarrollada, insertada en la superficie dorsal posterior del prostomio, y un pigidio conspicuo con dos cirros anales cortos digitiformes. Estas dos nuevas especies constituyen la primera cita de poliquetos simbiontes de bivalvos quimiosimbióticos en el Pacífico suroriental.

Palabras clave: afloramiento de metano, Nautiliniellidae, Antonbruunidae, poliquetos simbiontes, Chile.

\section{INTRODUCTION}

Benthic communities thriving in reducing habitats such as methane seeps and hydrothermal vents are constituted by rich invertebrate assemblages that host chemoautotrophic symbionts (e.g. Sibuet and Olu, 1998; Sibuet and Olu-Le Roy 2002; Sahling et al., 2002; Van Dover et al., 2003), as well as many heterotrophic species that also benefit from the chemosynthesis and methane-derived carbon (Bis- 
coito et al., 2002; Van Dover et al., 2003; Levin, 2005; Cordes et al., 2007). Communities of benthic animals associated with methane seeps (also known as cold seeps) have been found in several locations on active and passive continental margins of the Pacific and Atlantic Ocean (Olu et al., 1996; OluLe Roy et al., 2004; Ravara et al., 2007; Cordes et $a l .$, 2007). There have been some recent studies on the occurrence of cold seepage and gas hydrates on the central Chile margin (Morales, 2003; Sellanes et al., 2004, 2008). Clams dominate the chemosymbiotic fauna at a cold seep site located off central Chile $\left(36^{\circ} \mathrm{S}\right)$ called the Concepción Methane Seep Area (CMSA) (Sellanes et al., 2004; Sellanes and Krylova, 2005). The chemosymbiotic assemblages at the CMSA include vesicomyid, solemyid, lucinid and thyasirid bivalves (Sellanes and Krylova 2005; Holmes et al., 2005; Oliver and Sellanes, 2005), as well as a siboglinid tubeworm of the genus Lamellibrachia (Sellanes et al., 2008).

Vesicomyid bivalves are typical organisms of marine chemosynthesis-based communities (e.g. Sibuet and Olu-Le Roy, 2002; Van Dover et al. 2003; Sellanes et al., 2008). In the CMSA, the most frequently collected species is Calyptogena gallardoi, and two polychaete species belonging to the families Nautiliniellidae (Miura and Laubier, 1989) and Antonbruunidae Fauchald, 1977 were found within its mantle cavity. Nautiliniellids are a small group of polychaetes and all the species reported so far live as symbionts within deep-sea bivalve molluscs from hydrothermal vents and cold seeps (e.g. Miura and Laubier, 1989,
1990; Blake, 1993; Miura and Hashimoto, 1996; Dreyer et al., 2004; Ravara et al., 2007). This family has eleven genera, which are characterized by having a muscularized foregut, paired antennae, simple neuropodial hooks, and a rounded pygidium without anal cirri (Blake, 1993; Dreyer et al., 2004). However, the taxonomic status and ecology of this family are still not fully understood (Blake, 1993, 1997). The family Antonbruunidae was recognized by Fauchald (1977), and is closely related to the family Nautiliniellidae (Martin and Britayev, 1998). Antonbruunia viridis Hartmann and Boss, 1965, the only species described so far, is associated with the shallow water (62 to 82 m depth) bivalve mollusc Lucina fosteri Hartmann and Boss, 1965.

In fact, since both families are morphologically very close, it has been suggested that their taxonomic position should be redefined (see Martin and Britayev, 1998). The two new species described in this paper constitute the first report of symbiont polychaetes of chemosymbiotic bivalves in the south-eastern Pacific.

\section{MATERIALS AND METHODS}

\section{Study site}

The site is located $72 \mathrm{~km}$ NW off Concepción Bay, Chile, at the slope zone (750 to $900 \mathrm{~m}$ water depth) and near a mound separated by a shallow depression from another mound (Fig. 1). The pres-

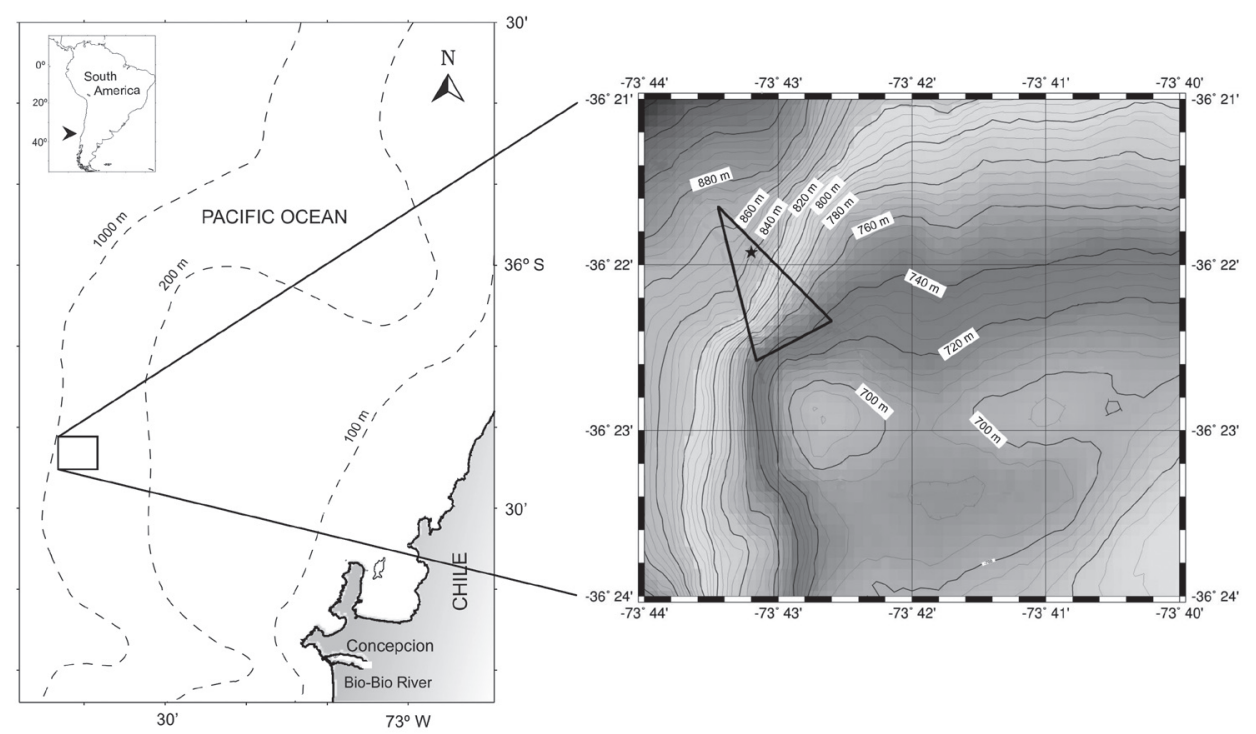

FIG. 1. - Study site, located on the slope zone off central Chile $\left(36^{\circ} \mathrm{S}\right)$. The triangle indicates the area in which trawls successfully collected evidence of active methane seepage (carbonate blocks, live chemosymbiotic clams and shell fragments). The star indicates the locations where shallow sub-surface gas hydrates have been observed. 


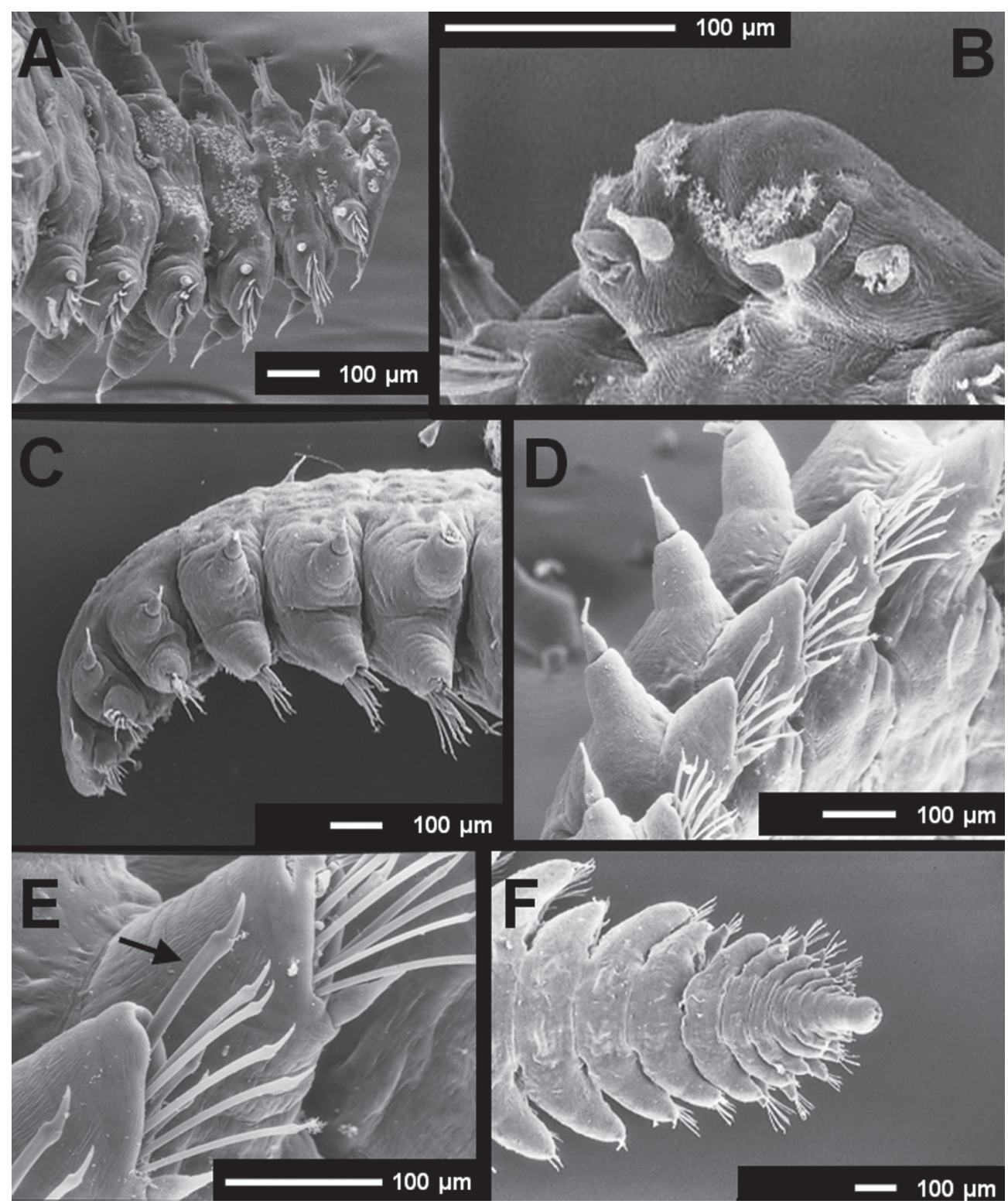

FIG. 2. - Shinkai robusta n. sp. (AGT10/VG-07): A, anterior region, ventral view; B, prostomiun, ventral view; C, anterior region, lateral view; $\mathrm{D}$, parapodia of the middle region; E, hooks of anterior parapodia (arrow showing a stout hook); F, pygidium, dorsal view.

ence of mounds and pockmarks has been previously documented for areas rich in subsurface gas hydrate deposits (Dando et al., 1991; Sassen et al., 2001, 2003). The sediment surface is characterized by the presence of abundant carbonate-cemented mud blocks (Sellanes et al., 2004, 2008), while high concentrations of methane and sulfide, as well as gas hydrates, have been documented in sediment cores (Coffin et al., 2006). Chemosymbiotic bivalves include vesicomyids, the solemyid Acharax sp., the lucinid Lucinoma anemiophila, and the thyasirids Thyasira methanophila and Conchocele sp. (Holmes et al., 2005; Oliver and Sellanes, 2005; Sellanes et al., 2008).

\section{Collection of samples}

Polychaete specimens were collected during oceanographic cruises conducted onboard RV "Vidal Gormáz" of the Chilean Navy during October 2004 (VG-04 cruise), September 2006 (SeepOx cruise), and September 2007 (VG-07 cruise). The biological material was obtained with an Agassiz trawl (mouth opening $1.5 \times 0.4 \mathrm{~m}$, mesh size $10 \times 10 \mathrm{~mm}$ at the cod-end) in 20 minute hauls.

Specimens of Calyptogena gallardoi were dissected onboard immediately after collection and polychaetes were extracted and fixed in $10 \%$ formalin and later preserved in $70 \%$ ethanol. Details of 

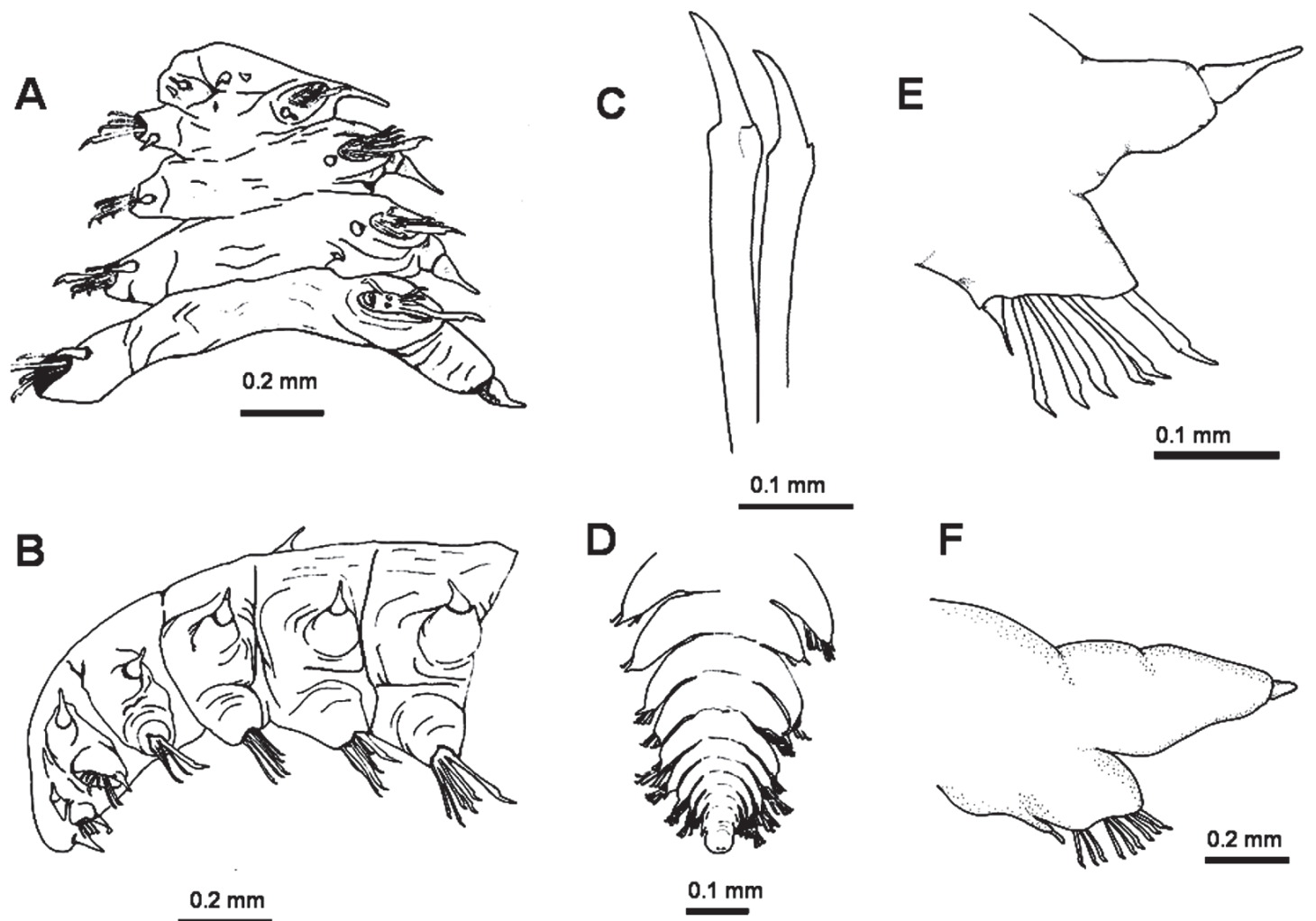

FIG. 3. - Shinkai robusta n. sp. (AGT10/VG-07): A, anterior region, ventral view; B, anterior region, lateral view; C, neuropodial hooks from parapodium 6; D, pygidium, dorsal view; E, parapodium 6 of the holotype; F, middle parapodium.

the setae were examined under immersion oil with a compound microscope. The terminology used follows Miura and Laubier (1989, 1990), Miura and Ohta (1991), Miura and Hashimoto (1993, 1996) and Blake (1990, 1993). Scanning electronic microscope (SEM) photographs were obtained (JEOL JSM-T300 microscope) of critical-point dried, gold coated specimens (JEOL JFC-1100 fine coat ion sputter; Rouse and Pleijel, 2001).

Type specimens are deposited in the "Museo Nacional de Historia Natural", Santiago, Chile (MNHNCL) and the reference collection of the Centre for Advance Studies in Patagonian Ecosystems (CIEP), Coyhaique, Chile.

\section{SYSTEMATIC ACCOUNT}

Family NaUtiLINIELLIDAE (Miura and Laubier, 1989) Genus Shinkai Miura and Laubier, 1990

Shinkai robusta n. sp. (Figs. 2 and 3)

Type material. Holotype (MNHNCL-AN2043), complete specimen, collected from the mantle cavity of Calyptogena gallardoi. Type locality: off Concepción, Chile (36²1'64”S,
7343'57’W), 865-926 m deep. October, 11, 2004 (AGT7/ VG04). Paratype (1 specimen, used for SEM photographs), complete specimen, collected from the mantle cavity of Calyptogena gallardoi. Type locality; off Concepción, Chile (36 $22^{\prime} 01^{\prime \prime}$ 'S, 734' 10”W), 764-843 m deep. October 02, 2007 (AGT10/VG07).

Description. (Holotype); complete specimen with 78 segments, measuring $13.86 \mathrm{~mm}$ long, 2.13 $\mathrm{mm}$ wide, including parapodia. Paratype; complete specimen with 82 setigers, measuring $19.20 \mathrm{~mm}$ long, $2.32 \mathrm{~mm}$ wide, including parapodia. Body elongated, vermiform, flattened ventrally, strongly arched dorsally and with longitudinal ventral groove. Colourless in alcohol. Prostomium short, sub-triangular with pair of small cirriform antennae, without eyes or other appendages. Mouth opening ventrally between prostomium and first setiger (Fig. 2A-C, $3 \mathrm{~A}-\mathrm{B})$. Foregut with well-developed muscular region without jaws and paragnaths. First segment partially fused with prostomium. Achaetous peristomial ring absent (Fig. 2C). Parapodia subbiramous with welldeveloped dorsal cirri and reduced ventral cirri (Fig. 2D-E and 3A-B, E-F). Neuropodia well developed, supported by single, stout neuroacicula; ventral cirri shorter than dorsal cirri (Fig. 3E, F). Anterior neuropodia with simple hooks (Fig. 3C), six on parapodia 
$1-10$, one of the hooks is stouter than the others (see Fig. 2C, E and 3C, E, F). Posterior neuropodia with up to nine simple hooks per neuropodium, all of them similar (Fig. 3F). Pygidium rounded, without anal cirri (Fig. 2F, 3D).

Remarks. The new species closely resembles the other congeneric species. In general, the parapodia and the head region of Shinkai robusta n. sp are similar to those of the Shinkai semilonga and Shinkai longipedata specimens; however, the main diagnostic characters are the shape of the neuropodial hooks, their number on each parapodium and the sub-triangular prostomium with a pair of small cirriform antennae. In fact, $S$. robusta $n$. sp. differs from all other species of the genus as it has anterior neuropodia with six hooks on parapodia 1-10, and one of the hooks is stouter than the others. In S. semilong $a$, the head and first eight setigers are depressed antero-posteriorly. The neuropodial hooks are simple and slightly curved at the distal end. The number of hooks per parapodium is about 15 on parapodia 1-3, and more than 25 on parapodia 4-6, then decreases to about ten on parapodium 10, and then five to eight on parapodia 50 to 200 (Miura and Hashimoto, 1996; Fig. 4A-E). In S. longipedata the middle and posterior parapodia are armed by a single neuropodial hook with a strongly curved distal fang (Fig. 4F-I; Miura and Hashimoto, 1996; Dreyer et al., 2004). Shinkai sagamensis differs from the above three species as it has very short notopodia and a different number of hooks on each parapodium (Fig. 4J-L). In fact, several hooks projected from each neuropodium on the anterior parapodia, e.g. 3-4 on parapodium 1, 5-8 on parapodia $2-6,1-3$ on parapodia $7-20$ and 1 on the posterior parapodia (Miura and Laubier, 1990).

Habitat. All previously known nautiliniellid species are symbionts associated with bivalve molluscs from cold seeps or hydrothermal vents (Table 1). The genus Shinkai is close to Nautiliniella, but differs in having up to eight hooks per neuropodium instead of one, and a single pair of antennae instead of two. In contrast, Natsushima differs from the other two genera as it has two types of neuropodial spines instead of only one (Blake, 1993). The genus Shinkai comprises, at present, three described species: Shinkai longipedata Miura and Otha, 1991, Shinkai semilonga Miura and Hashimoto, 1996 and Shinkai sagamensis Miura and Laubier, 1990, all from Japan. The occurrence rate in bivalves of $S$.

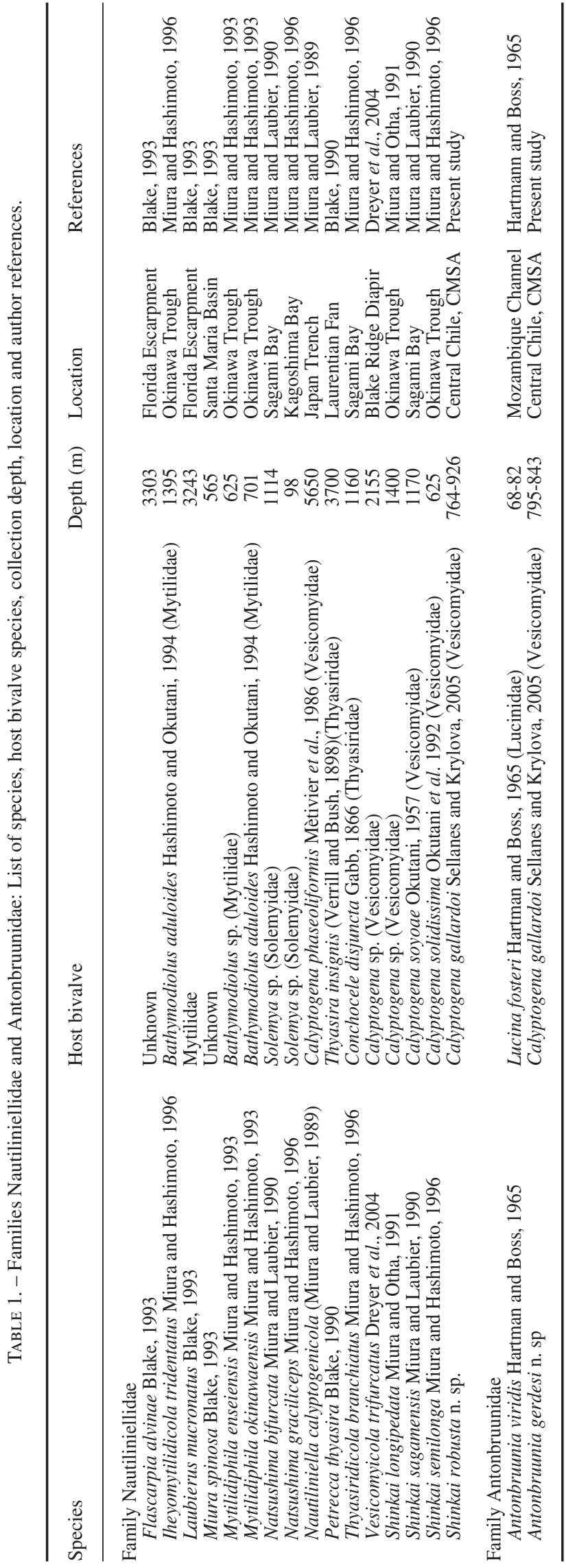



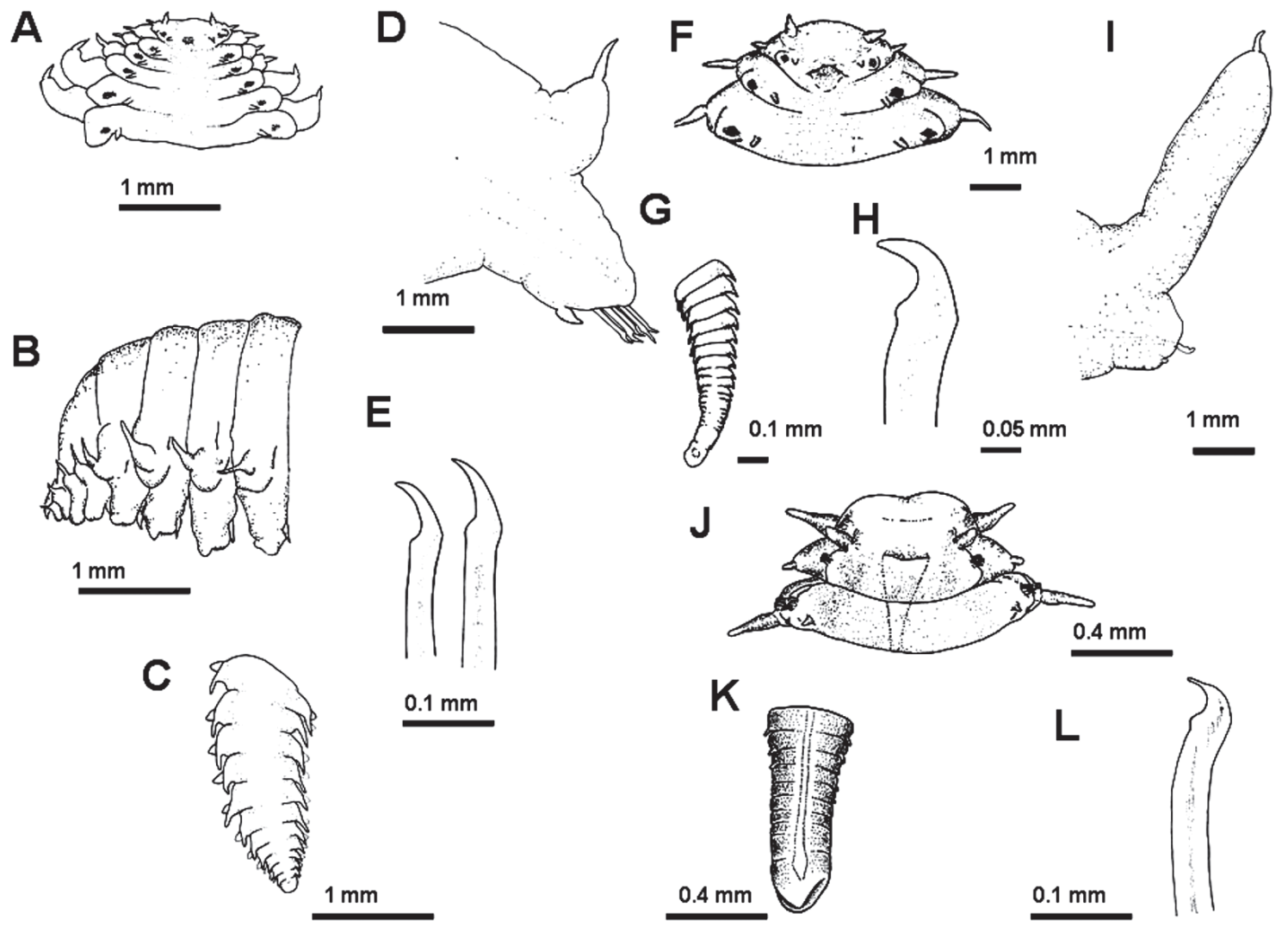

FIG. 4. - Shinkai semilonga (after Miura and Hashimoto, 1996): A, anterior region, dorsal view; B, anterior region, lateral view; C, pygidium, dorsal view; D, parapodium 100; E, neuropodial hooks. Shinkai longipedata (after Miura and Otha, 1991): F, anterior region, dorsal view; G, pygidium, dorsal view; H, neuropodial hook; I, parapodium 100. Shinkai sagamensis (after Miura and Laubier, 1990): J, anterior region, dorsal view; K, pygidium, dorsal view; L, neuropodial hook.

robusta $\mathrm{n}$. sp. is very low, and only two of the 35 specimens of $C$. gallardoi analyzed hosted a single individual of this polychaete species.

Distribution. Only known from the type locality off Concepción, at a depth of 764 to 926 m. Shinkai robusta $\mathrm{n}$. sp. is the first nautiliniellid species reported at a cold seep site in the south-eastern Pacific area. To date, its host bivalve C. gallardoi is also only known from the type locality.

Etymology. The species' name is derived from their characteristically elongated and robust notopodia.

Family AntonbruUnidae Fauchald, 1977

Genus Antonbruunia Hartman and Boss, 1965

Antonbruunia gerdesi $\mathrm{n}$. sp.

(Figs. 5 and 6)

Type material. Holotype (MNHNCL-AN2044), complete specimen, collected from the mantle cavity of Calyptogena gallardoi. Type locality; off Concepción, Chile (36²2'19'’S, 7343’36”W),
843-846 m deep. 04 September, 2004 (AGT6-9/SeepOx). Paratype (1 specimen, used for SEM photographs), complete specimen, collected from the mantle cavity of Calyptogena gallardoi. Type locality; off Concepción, Chile ( $\left.36^{\circ} 21^{\prime} 93^{\prime \prime} \mathrm{S}, 73^{\circ} 42^{\prime} 84^{\prime \prime} \mathrm{W}\right), 795-843 \mathrm{~m}$ deep. 02 September, 2006 (VG-06/SeepOx).

Description. (Holotype); complete specimen with 33 segments, measuring $5.86 \mathrm{~mm}$ long, 1.10 $\mathrm{mm}$ wide, including parapodia. Paratype; complete specimen with 53 segments, measuring $16.40 \mathrm{~mm}$ long, $2.04 \mathrm{~mm}$ wide, including parapodia. Body vermiform, flattened ventrally, slightly arched dorsally, without longitudinal ventral groove (Fig. 5A-C, and Fig 6A). Colour green in life, white after preservation. Prostomium short and trapezoidal with five sub-equal cirriform antennae, including an unpaired median antenna, without eyes or other appendages. Frontal antennae shorter, inserted ventrally on prostomium (Fig. 5A, B and 6B). Median antenna inserted posteriorly on the dorsal surface of the prostomium. Pharynx without jaws, paragnaths. Peristomial achaetous ring with two pairs of long, well-developed cirri (Fig. 5A, $\mathrm{B}$ and $6 \mathrm{~B})$. Parapodia increasing gradually to the postanterior and mid-body region (Fig. 5A). All parapo- 


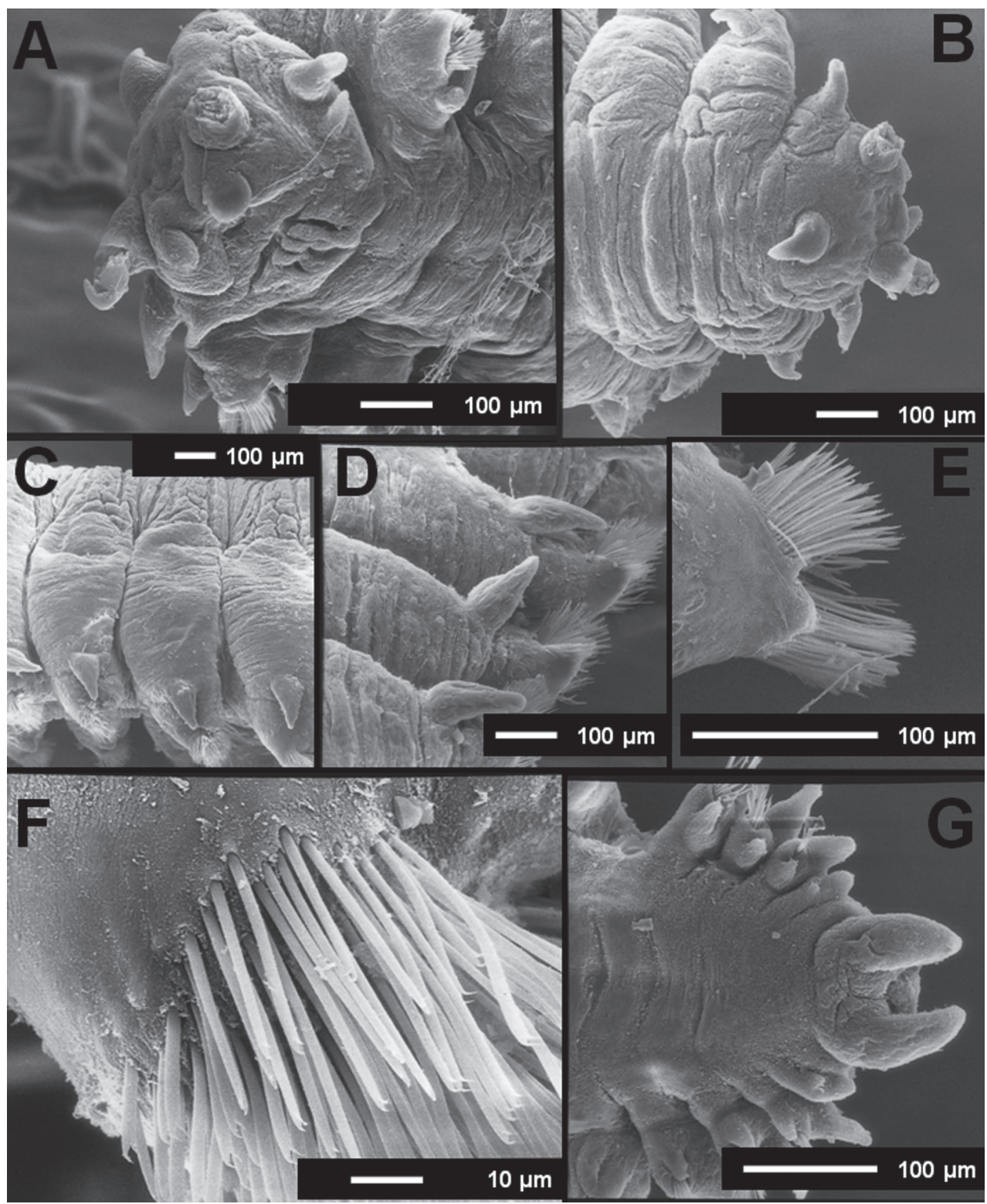

FIG. 5. - Antonbruunia gerdesi n. sp. (AGT6-9/SeepOx): A, anterior region, ventral view; B, anterior region, dorsal view; C, parapodia of the middle region lateral view; D, parapodia of the middle region, ventral view, E, hooks of the middle region; F, hooks; G, pygidium, ventral view.

dia subbiramous (Fig 5C-E and 6C). Notopodia with dorsal cirrus and a slender embedded notoaciculum, straight and pointed. All setae simple with long straight shaft, bifid, with two straight teeth of similar length (Fig. 5E, F and 6B, D). Pygidium conspicuous, with two well-developed digitiform cylindrical anal cirri (Fig. 5G, 6C).

Remarks. Antonbruunia gerdesi n. sp. differs from $A$. viridis in the shape of its notopodia (elongated and wide), and the presence of five sub-equal occipital antennae on the prostomium (Fig. 6A-D, 6F-H). The hooks of $A$. gerdesi n. sp are simple, with a long, straight, distally bifid shaft (Fig. 6E). In contrast, those of $A$. viridis are curved distally (Miura and Laubier, 1990; Fig. 6H). The only known species that represents the family Antonbruunidae so far, Antonbruunia viridis inhabits the mantle cavity of its host bivalve Lucina fosteri (Table 1), which occurs in hypoxic sediments of black-brown oozy mud and detritus, off the coast of Mozambique, Indian Ocean (Hartman and Boss, 1965).

Habitat. The host bivalve of A. gerdesi n. sp. (C. gallardoi) is only known from the type locality in the south-eastern Pacific (Sellanes and 

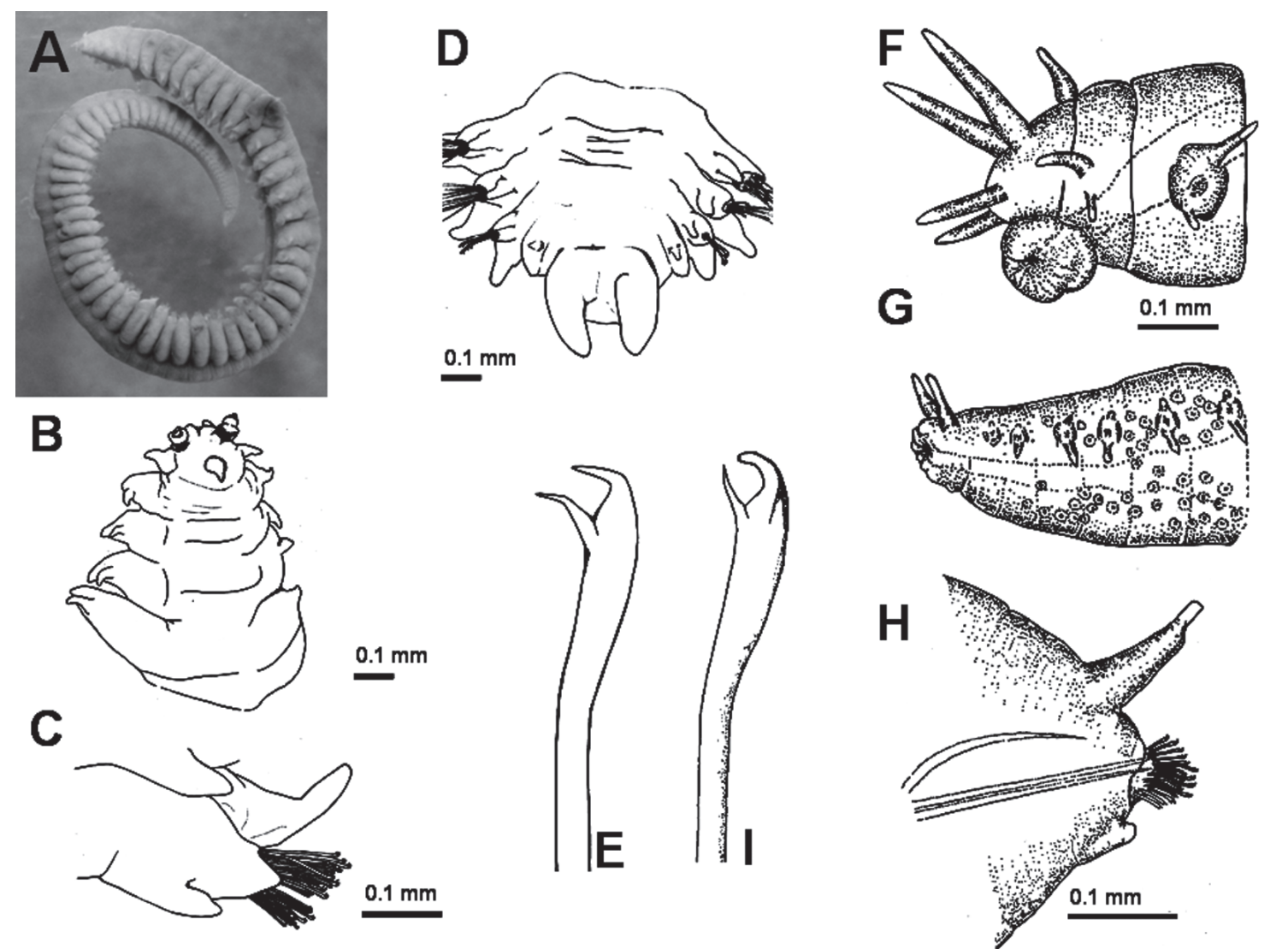

FIG. 6. - Antonbruunia gerdesi n. sp. (AGT6-9/SeepOx): A, photography of whole body, lateral view; B, anterior region, dorsal view; C, middle parapodium; D, pygidium, ventral view; E, hook. Antonbruunia viridis Hartman and Boss, 1965 (after Miura and Laubier, 1990): F, anterior region, lateral view; G, pygidium, lateral view; H, posterior parapodium; I, hook (after Hartman and Boss, 1965).

Krylova, 2005), where it inhabits sticky dark grey sediments smelling of sulphide. Carbonate crusts also occur in the area, and gas hydrates were retrieved from subsurface sediments nearby. Like the other species described in the present study, the occurrence rate of A. gerdesi n. sp. is low: four of the 35 specimens of $C$. gallardoi analyzed hosted an individual of this polychaete. Although in general each bivalve hosted a single polychaete, three specimens were found in one host bivalve that measured $9 \mathrm{~mm}$ long. It is also worth noting that no co-occurrence of $A$. gerdesi n. sp. and $S$. robusta $\mathrm{n}$. sp. has been observed within a single specimen of $C$. gallardoi, but to our knowledge this is the first time that two different polychaete species have been found associated with the same vesicomyid host species.

Distribution. Only known from the type locality off Concepción (Chile), 795-846 m depth. Antonbruunia gerdesi n. sp. is the second known species of the family, the first antonbruunid found in the Pacific Ocean, and the first report of the family at a cold seep site.
Etymology. The species is named in honour of Dr. Dieter Gerdes (Alfred Wegener Institute for Polar and Marine Research, Germany) who has studied marine benthic communities of the South American and Antarctic margins extensively.

\section{ACKNOWLEDGEMENTS}

Our thanks go to the officers and crew of R/V Vidal Gormáz for their skilful operations at sea. We thank Juan Diaz Naveas (PUCV, Chile) for providing onboard facilities during the VG-04 and VG-07 cruises. Taxonomic literature was provided by Dr. Dieter Gerdes (AWI, Germany) and Dr. Guillermo San Martin (UAM, Spain). We are also very grateful to Maria Soledad Romero, Universidad Católica del Norte (Coquimbo) for help in the preparation of the specimens and SEM work. We thank Paula Ortiz Saini for her patience and dedication in preparing the drawings. The manuscript benefited from reviews by Jennifer Dreyer (Virginia Institute of Marine Science, USA), Guillermo Guzmán (Universidad Arturo Prat, Chile), Dr. Américo Mon- 
tiel (Universidad de Magallanes, Chile) and insightful comments provided by Dr. Tomoyuki Miura and an anonymous reviewer. This research was supported by the FONDECYT \#1061217 project. The FONDECYT \#1061214 and FONDAP-COPAS \#15010007 projects contributed extra funding for shiptime. We thank the CIEP center (Gobierno Regional de Aysen, Chile, BIP, No. 3004258-0) for their support during the writing phase of this work.

\section{REFERENCES}

Biscoito, M., M. Segonzac, A.J. Almeida, D. Desbruyeres, P. Geistdoerfer, M. Turnipseed and C.L. Van Dover. - 2002. Fishes from the hydrothermal vents and cold seeps - An update. Cah Biol. Mar., 43: 359-362.

Blake, J. - 1990. A new genus and species of polychaeta commensal with a deep-sea thyasirid clam. Proc. Biol. Soc. Wash., 103 681-686.

Blake, J. - 1993. New genera and species of deep-sea species Polychaetes of the family Nautiliniellidae from the Gulf of México and Eastern Pacific. Proc. Biol. Soc. Wash., 106: 147-157.

Blake, J. - 1997. Family Nautiliniellidae Miura and Laubier, 1990. In: J. Blake, B. Hilbig and P. Scott (eds.), Taxonomic Atlas of the benthic fauna of the Santa Maria Basin and the Western Santa Barbara Channel. Volume 4, the annelid, part 2, Oligochaeta and Polychaeta: Phyllodocida (Phyllodocidae to Paralacydoniidae), pp 1-369. Santa Barbara Museum of Natural History, Santa Barbara California.

Coffin, R., J. Gardner, J. Diaz and J. Sellanes. - 2006. Gas Hydrate Exploration, Mid Chilean Coast; Geochemical-Geophysical Survey. NRL/MR/6110-06-9006. Tech. Rep., 1-61. Available at: http://handle.dtic.mil/100.2/ADA461588

Cordes, E.E., S.L. Carney, S. Hourdez, R.S. Carney, J.M. Brooks and C.R. Fisher. - 2007. Cold seeps of the seed Gulf of Mexico: community structure and Biogeographic comparisons to Atlantic equatorial belt seep communities. Deep-Sea Res I., 54: 637-653.

Dando, P.R., M.C. Austen, R.A. Burke, M.A. Kendall, M.C. Kennicutt II, A.C. Judd, D.C. Moore, S.C. O'Hara, R. Schmaljohann and A.J. Southward. - 1991. Ecology of a North Sea pockmark with an active methane seep. Mar. Ecol. Prog. Ser., 70: 49-63.

Dreyer, J., T. Miura and C.L. Van Dover. - 2004. Vesicomyicola trifurcatus, a new genus and species of commensal polychaete (Annelida: Polychaeta : Nautiliniellidae) found in deep-sea clams from the Blake Ridge cold seep. Proc. Biol. Soc. Wash., 117(1): 106-113.

Fauchald, K. - 1977. The polychaete worms. Definitions and keys to orders, families and genera. Nat. Hist. Mus. Los Angeles Count. Sci. Ser., 28: 1-188.

Hartmann, O. and K. Boss. - 1965. Antonbruunia viridis, a new inquiline annelid with dwarf males, inhabiting a new species of pelecypod, Lucina fosteri in Mozambique Channel. Ann. Mag. Nat. Hist. Ser., 13(8): 177-186

Holmes, A.M., P.G. Oliver and J. Sellanes, - 2005. A new species of Lucinoma (Bivalvia: Lucinoidea) from a methane gas seep off the south west coast of Chile. J. Conch., 36(6): 673-681.

Levin, L.A. - 2005. Ecology of cold seep sediments: interactions of fauna with flow, chemistry and microbes. Oceanogr. Mar. Biol. Annu. Rev., 43: 1-46.

Martin, D. and T.A. Britayev. - 1998. Symbiotic polychaetes: review of known species. Oceanogr. Mar. Biol. Annu. Rev., 36: 217-340.

Miura, T. and J. Hashimoto. - 1993. Mytilidiphila, a new genus of nautiliniellid polychaetes living in the mantle cavity of deepsea mytilid bivalves collected from the Okinawa Through. Zool. Sci., 10: 169-174.

Miura, T. and J. Hashimoto. - 1996. Nautiliniellid polychaetes living in the mantle cavity of bivalve molluscs from cold seeps and hydrothermal vents around Japan. Publ. Seto. Mar. Lab.
37(316): 257-274

Miura, T. and L. Laubier. - 1989. Nautilina calyptogenicola, a new genus and species of parasitic polychaete on a vesicomyid bivalve from the Japan Trench, representative of a new family Nautilinidae. Zool. Sci., 6: 387-390.

Miura, T. and L. Laubier. - 1990. Nautiliniellid Polychaetes collected from the Hatsushima cold-seep site in Sagami Bay with descriptions of new genera and species. Zool. Sci., 7: 319-325.

Miura, T. and S. Otha - 1991. Two polychaete species from the deep-sea hydrothermal vent in the Middle Okinawa Trough. Zool. Sci., 8: 383-387.

Morales, E. - 2003. Methane hydrates in the Chilean continental margin. Biotechnology Issues for Developing Countries, 6: 80-84.

Oliver, P.G. and J. Sellanes. - 2005. New species of Thyasiridae from a methane seepage area off Concepción, Chile. Zootaxa, 1092: $1-20$

Olu, K., A. Duperret, M. Sibuet, J.P. Foucher and A. Fiala-Medioni. - 1996. Structure and distribution of cold seep communities along the Peruvian active margin: relationship to geological and fluid patterns. Mar. Ecol. Progr. Ser., 132: 109-125.

Olu-Le Roy, K., M. Sibuet, A. Fiala-Médioni, S. Gofas, C. Salas, A. Mariotti, J.-P. Foucher and J. Woodside. - 2004. Cold seep communities in the deep eastern Mediterranean Sea: composition, symbiosis and spatial distribution on mud volcanoes. Deep-Sea Res. I., 51: 1915-1936.

Rouse, G.W. and F. Pleijel. - 2001. Polychaetes. Oxford University Press, New York.

Ravara, A., M. Cunha and C. Rodrigues. - 2007. The occurrence of Natsushima bifurcata (Polychaeta: Nautiliniellidae) in Acharax host from mud volcanoes in the Gulf of Cadiz (south Iberian and north Moroccan Margins). Sci. Mar., 71(1): 95-100.

Sahling, H., D. Rickert, R.W. Lee, P. Linke and E. Suess. - 2002. Macrofaunal community structure and sulfide flux at gas hydrate deposits from the Cascadia convergent margin. Mar. Ecol. Progr. Ser., 231: 121-138.

Sassen, R., L.L. Losh, L. Cathles III, H.H. Roberts, J.K. Whelan, A.V. Mildov, S.T. Sweet and D.A. DeFreitas. - 2001. Massive vein-filling gas hydrate: relation to ongoing gas migration from the deep subsurface in the Gulf of Mexico. Mar. Petrol. Geol., 18: $551-560$

Sassen, R., A.V. Milkov, H.H. Roberts, S.T. Sweet and D.A. DeFreitas. - 2003. Geochemical evidence of rapid hydrocarbon venting from a seafloor-piercing mud diapir, Gulf of Mexico continental shelf. Mar. Geol., 198: 319-329.

Sellanes, J. and E. Krylova. - 2005. A new species of Calyptogena (Bivalvia, Vesicomyidae) from a recently discovered methane seepage area off Concepción Bay, Chile $\left(\sim 36^{\circ} \mathrm{S}\right)$. J. Mar. Biol. Ass. U.K., 85: 969-976.

Sellanes, J., E. Quiroga and V.A. Gallardo. - 2004. First direct evidences of methane seepage and associated chemosynthetic communities in the bathyal zone off Chile. J. Mar. Biol. Ass. U.K., 84: 1065-1066.

Sellanes, J., E. Quiroga and C. Neira. - 2008. Megafaunal community structure and trophic relationships of the recently discovered Concepción Methane Seep Area (Chile, $\left.\sim 36^{\circ} \mathrm{S}\right)$. ICES J. Mar. Sci., 65: 1102-1111.

Sibuet, M. and K. Olu. - 1998. Biogeography, biodiversity and fluid dependence of deep-sea cold-seep communities at active and passive margins. Deep-Sea Res. II., 45: 517-567.

Sibuet, M. and K. Olu-Le Roy. - 2002. Cold seep communities on continental margins: structure and quantitative distribution relative to geological and fluid venting patterns. In: G. Weffer, D. Billett, D. Hebbeln, B.B. Jorgersen and T.J. Van Weering (eds.), Ocean Margin Systems pp. 235-251. Springer-Verlag, Berlin.

Van Dover, C.L., P. Aharon, J.M. Berhard, E. Caylor, M. Doerries, W. Flickinger, W. Gilhooly, S.K. Goffredi, K.E. Knick, S.A. Macko, S. Rapoport, E.C. Raulfs, C. Ruppel, J.L. Salerno, R.D. Seitz, B.K. Sen Gupta, T. Shank, M. Turnipseed and R. Vrijenhoek. - 2003. Blake Ridge methane seeps: characterization of a soft-sediment, chemosynthetically based ecosystem. Deep-Sea Res. I., 50: 281-300.

Scient. ed.: D. Martin.

Received March 5, 2008. Accepted October 17, 2008.

Published online March 12, 2009. 
